Int. J. Dev. Biol. 57: 201-210 (2013)

doi: $10.1387 / \mathrm{ijdb} .130136 \mathrm{bc}$

\title{
Testicular teratomas: an intersection of pluripotency, differentiation and cancer biology
}

\author{
XIMENA BUSTAMANTE-MARÍN ${ }^{1,2}$, JASON A. GARNESS ${ }^{1}$ and BLANCHE CAPEL ${ }^{*, 1}$ \\ ${ }^{1}$ Department of Cell Biology, Duke University Medical Center, Durham, N.C., USA and \\ ${ }^{2}$ Facultad de Ciencias de la Salud, Departamento Biomédico Universidad de Antofagasta, Antofagasta, Chile
}

\begin{abstract}
Teratomas represent a critical interface between stem cells, differentiation and tumorigenesis. These tumors are composed of cell types representing all three germ layers reflecting the pluripotent nature of their cell of origin. The study of these curious tumors became possible when Leroy Stevens identified the $\mathbf{1 2 9}$ mouse strain as a model of spontaneous testicular teratoma and later isolated a substrain carrying the Ter mutation, a potent modifier of tumor incidence. Early studies with 129 mice lead to the discovery of embryonal carcinoma (EC) cells which played a foundational role in the embryonic stem (ES) cell field and the study of pluripotency. The cells of origin of testicular teratomas are germ cells. During early development, primordial germ cells diverge from somatic differentiation and establish their pluripotent nature, maintaining or re-expressing core pluripotency genes; Oct4, Sox2 and Nanog. It is believed that a misregulation of male germ cell pluripotency plays a critical role in teratoma development. Several mouse models of teratoma development have now been identified, including a chromosome substitution strain, 129-Chr19MOL, conditional Dmrt1 and Pten alleles and the Ter mutation in the Dnd1 gene. However, it is still unknown what role somatic cells and/or physiology play in the sensitivity to teratoma development. These unusual tumors may hold the key to understanding how pluripotency is regulated in vivo.
\end{abstract}

KEY WORDS: testicular teratoma, germ cell, Dnd1, stem cell

\section{Introduction}

Testicular teratomas, which originate from germ cells, are tumors in which cell types representing all three germ layers are found. From their earliest discovery, teratomas fascinated scientists because they implied the presence of pluripotent cells within a differentiated organism that could escape along a disordered differentiation pathway and undergo tumorigenesis. Teratomas represent a critical interface between fields devoted to the study of stem cells, differentiation, and tumorigenesis. Investigators hope that these unusual tumors hold the key to understanding how pluripotency is secured versus how unrestrained growth and/or differentiation are activated in stem cells. These issues are central to cancer, stem cell biology, and regenerative medicine. In this review, we will briefly place teratomas (benign) and teratocarcinomas (malignant) within the classification of testicular germ cell tumors (TGCTs). We will discuss the history of the teratoma/teratocarcinoma field (hereafter referred as teratoma) and review how the early work on teratomas in mice led to embryonic stem cell research. We will then recap recent progress toward a molecular understanding of teratoma susceptibility and origins in the context of our current understanding of germ cell development.

\section{Teratoma is the most common TGCT in young men}

TGCTs account for approximately $96 \%$ of all testicular tumors, and are the most common cancer in men between the ages of 20 and 39 (Richardson et al., 2008). The worldwide incidence of TGCT has doubled in the past 30 years. In the United States approximately 8,590 new TGCT cases and 360 TGCT-related deaths are estimated for $2012(\mathrm{NCl}, 2012)$. All TGCTs are believed to arise from a common precursor called carcinoma in situ (CIS), which has variable differentiation potential (Looijenga et al., 2011). The International Classification of Diseases for Oncologygrouped TGCT

\footnotetext{
Abbreviations used in this paper: DND1, dead-end homolog 1; DMRT1, Doublesex and mab-3 related transcription factor 1; EC, embryonal carcinoma cell; EG, embryonic germ cell; ES, embryonic stem cell; iPS, Induced pluripotent stem cells; PGC, pri $\neg$ mordial germ cell; PTEN, phosphatase and tensin homolog; Sl or Sl-J, alleles of Steel, aka Kitl; TGCT, testicular germ cell tumor.
}

\footnotetext{
*Address correspondence to: Blanche Capel. 4034 GSRBII Research Drive, Durham, NC 27710, USA. Tel: +1-919-684-6390. Fax: +1-919-668-3467.

E-mail: blanche.capel@ duke.edu - web: http://www.cellbio.duke.edu/faculty/Capel/Capel_Lab_Site/Site/Welcome.html
} 
into two broad categories of tumors: seminoma and non-seminoma. Seminomas, which are relatively low in malignancy, arise from differentiated germ cells whereas non-seminomas arise from pluripotent germ cells and have a more clinically aggressive phenotype. The International Agency for Research on Cancer recognizes specific subtypes of non-seminomas initially proposed by Dixon and Moore in 1953 (Dixon and Moore, 1953; Egevad et al., 2007): embryonal carcinomas, teratomas, yolk sac tumors, and choriocarcinomas. The histology of these tumors frequently shows a mixture of tumor subtypes (Fig. 1A).

The most common type of TGCT in young men and during early childhood is testicular teratoma (TCS, 2012). World Health Organization (WHO) classification recognizes three histological subtypes of teratoma: mature, immature, and teratocarcinomas. These tumors show high histological diversity and contain a variety of tissue elements derived from all three germ layers (Fig. 1C,C') (Stevens and Little, 1954), consistent with the pluripotent state of the cells that give rise to them. Teratomas are among the oldest known tumors, referenced first in a Babylonian document four thousand years ago (Pantoja and Rodriguez-lbañez, 1976). These tumors were recognized as a curiosity from the earliest days of their discovery in humans. Perhaps the disorganized embryonic features of these tumors explains why in 1863 Rudolf Virchow, a German Pathologist, introduced the term "teratoma" from the Greek root teras meaning marvel or monster (Pantoja and Rodriguez-lbañez, 1976).

\section{Establishing an experimental model for teratoma}

Apart from their clinical relevance, teratomas occupy a critical position along the timeline of stem cell research (Solter, 2006).
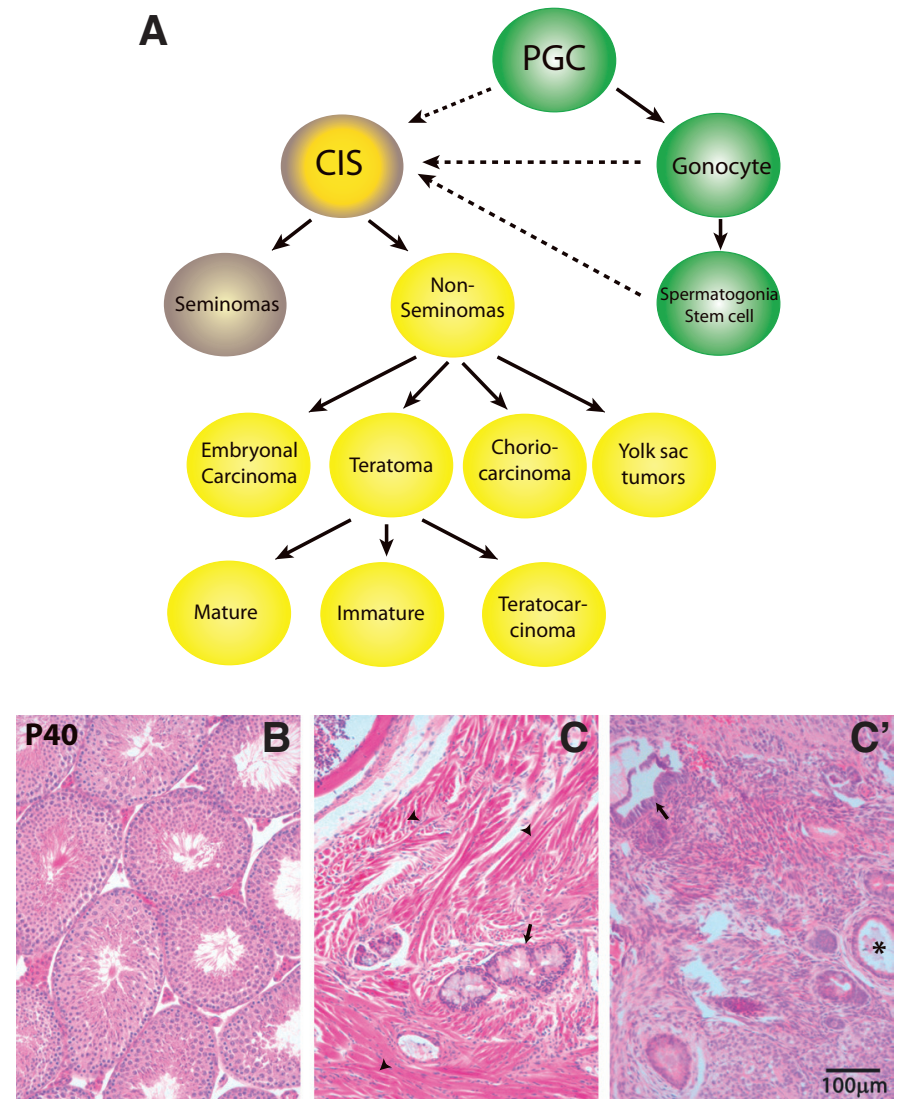

Teratomas found in humans and horses attracted the interest and curiosity of investigators, who recognized that the histological diversity of teratomas implied the presence of a cell or cells with pluripotent capability within a differentiated organism. However, it was not until the 1950's, when Leroy Stevens identified an inbred mouse strain, $129 / \mathrm{Sv}$, with a $1 \%$ incidence of spontaneous testicular teratoma (Stevens and Little, 1954), that experimental work began and played a foundational role in the development of the stem cell field.

Stevens recognized that mice in which a high percentage of males developed testicular teratomas would be a valuable tool to study the origin and biology of these tumors. In subsequent years, Stevens isolated a few substrains with slightly higher incidence of spontaneous teratomas, one by introducing a Steel mutation onto the 129/Sv genetic background (129/Sv ${ }^{\text {II }}$ ) (Stevens and Mackensen, 1961). In the course of other backcrosses, Stevens isolated a single female with a spontaneous mutation, whose offspring showed a high teratoma incidence. From this female, Stevens established the strain, 129/Sv ${ }^{\text {Ter }}$. Intercrosses between individuals in this strain yielded a $30 \%$ teratoma incidence (Stevens, 1973), rendering the study of the etiology and biology of these rare tumors experimentally tractable for the first time.

Through an exhaustive histological analysis of testicular teratomas, Stevens observed continuity between the germinal epithelium of testicular tubules and the neoplastic epithelium that formed teratomas. The testicular tubules were enlarged by the presence of neoplastic cells and the basement membrane was disrupted, giving the appearance that pressure due to growth had ruptured the seminiferous epithelium, spilling out tumor cells (Stevens, 1959). These observations and other reports (Falin, 1940, Melicow, 1955), supported the hypothesis that testicular teratomas originate within the tubules, most likely from germ cells.

Stevens found that he could induce teratomas by grafting the genital ridges from developing 129/Sv embryos onto the testes of adult mice; however, the incidence of teratomas generated in this manner sharply declined when the graft came from an embryo older than E12.5 (Stevens, 1964), suggesting that the pluripotency of the testicular cell of origin is stage specific (Fig. 2A Table 1). These observations suggested to Stevens that teratomas originate from germ cells prior to their stable differentiation to spermatogonia. To address the question of the origin of testicular teratomas experimentally, Stevens grafted genital ridges of embryos from a 129/

Fig. 1. Germ cell origins of testicular tumors. (A) In normal development PGCs differentiate into gonocytes, which become spermatogonial stem cells. Neoplastic development of PGCs, gonocytes, or spermatogonial stem cells is believed to give rise to carcinoma in situ (CIS) cells, the precursors of all types of TGCT. The International Classification of Diseases for Oncology divided TGCT in two broad categories: seminoma and non-seminoma. In humans approximately $61 \%$ of all germ cell tumors are pure seminomas. The remaining are non-seminomas which originate from pluripotent germ cells and include five histological groups: embryonal carcinomas, teratomas, choriocarcinomas, yolk sac tumors, and mixtures of two or more of these tumor types. Teratomas can be composed of differentiated cell types (mature), embryonic cell types (immature), or transformed undifferentiated EC cells (teratocarinoma). (B) Histological section of control 40 dpn 129/ $S v$ testis stained with $H \& E$. (C, $\left.\mathbf{C}^{\prime}\right)$ Examples of testicular teratomas in a $40 \mathrm{dpn} 129 / \mathrm{Sv}$ mouse testis. The normal morphology of the seminiferous epithelium has been replaced by the tumor with a diverse array of tissue types including muscle (arrow head) and glandular (arrow) tissue. A remnant of a degenerating tubule $\left(^{*}\right)$ can be observed. 
A

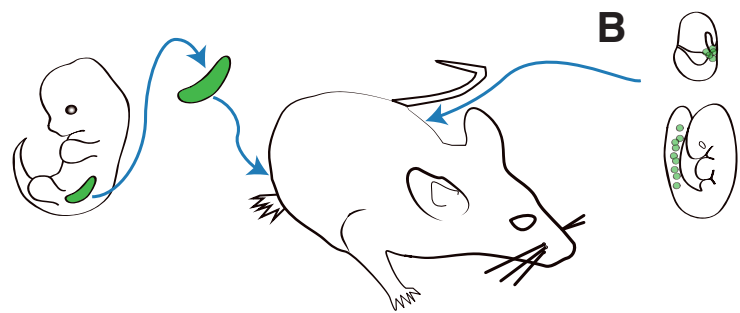

Table 1: Stevens's Experiments

\begin{tabular}{|c|c|c|}
\hline Genital ridge age & \multicolumn{1}{c}{ E12.5 } & E13.5 \\
\hline Graft site & Teratoma (\%) & Teratoma (\%) \\
\hline Testis & 82 & 8 \\
\hline Spleen & 9 & - \\
\hline
\end{tabular}

Table 2: Solter's Experiments

\begin{tabular}{|c|c|c|c|}
\hline Embryo stage & \multicolumn{2}{c}{ E6.5 } & \multicolumn{2}{c}{ E7.5 } & E8.5 \\
\hline Graft site & Teratoma (\%) & Teratoma (\%) & Teratoma (\%) \\
\hline Kidney capsule & 100 & 100 & 100 \\
\hline
\end{tabular}

Fig. 2. Experimental induction of teratoma development. Two lines of experiments were conducted to investigate the origin of teratomas. (A) In Stevens's experiments, teratocarcinogenesis was induced by grafting the genital ridges of developing $129 / \mathrm{Sv}^{\text {slJ }}$ heterozygous mice into the testes of adult mice. He observed that the incidence of teratomas was strongly influenced by the age and site of the graft. (B) In Solter's experiments, when post-implantation embryos at stage: E6.5, E7.5, and E8.5 were transplanted under the kidney capsule, 100\% developed into teratomas. Solter deduced that germ cells and embryonal carcinomal cells have similar characteristics.
$\mathrm{Sv}^{S / /+} \times 129 / \mathrm{Sv}^{S / /+}$ cross to the testes of adults. Seventy-five percent of the heterozygous and wild type genital ridges developed into testes with teratomas as expected. However, few teratomas were

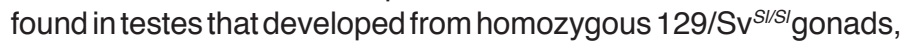
which were depleted of germ cells (Stevens, 1967). This experiment bolstered the evidence that teratomas arise from germ cells.

Solter also generated teratomas by grafting post-implantation rat and mouse embryos to the subcapsular space of the kidney (Damjanov et al., 1971, Solter et al., 1980) (Fig. 2B Table 2). The teratomas generated by this method were histologically identical to those that arose spontaneously in 129/Sv mice. From these results Solter deduced that the cell(s) of origin of teratomas, both those derived from the embryo and those derived from the genital ridge, had similar characteristics. These results implied that germ cells and embryonal cells from the egg cylinder had a similar susceptibility to develop teratomas, but the nature of that susceptibility was unknown.

\section{From teratomas to stem cell biology}

It was conceivable that the complex array of tissues detected in a teratoma arose from a mixture of originating cells. Previous experiments showed that teratomas could be serially propagated by transplantation of a tumor fragment (Stevens and Little, 1954), suggesting that a tumor stem cell might exist within the tumor. Histological analysis of teratomas revealed clusters of undifferentiated cells within the tumors (Stevens, 1959). Direct evidence for the presence of tumor stem cells was provided by Kleinsmith and Pierce in 1964 through an in vivo cloning technique. Embryonal carcinoma (EC) cells were purified from a subline of a transplanted teratoma isolated by Stevens. A single EC cell was injected intraperitoneally into 129/Sv mice and produced teratomas composed of different cell types (Kleinsmith and Pierce, 1964). The demonstration that a single cell derived from a teratoma could produce all cell types encountered in a teratoma was a crucial experiment. With this finding began the derivation and characterization of mouse and human cell lines that could retain their pluripotency (Holden et al., 1977). The microinjection of EC cells into the blastocoel of developing embryos, showed that EC cells could contribute to all tissues of the host embryo (Brinster, 1974, Mintz and Illmensee, 1975). However, their contributions were often limited, and tumors frequently arose in the chimeric animals (Papaioannou et al., 1975). Despite this, investigators began to realize that the availability of a population of stem cells that could be cultured indefinitely presented an opportunity to modify the genome (Mintz and Fleischman, 1981). It was shown that when EC cells were mutagenized, selected, and introduced into a blastocyst, they could contribute to germ line progeny that perpetuated the induced/introduced-genetic change in a new mouse strain. In the first experiment, EC cells deficient for hypoxantine phosphoribosyl transferase (Hprt-) were selected and injected into a blastocyst. In the chimeric mice that resulted, mature functional cells retained the HPRT deficiency (Mintz and Fleischman, 1981). The idea that this experimental system could be used to directly generate animal models of human genetic disease was emerging.

The derivation of teratomas from pre- and post-implantation embryo transplants suggested that pluripotent stem cells could be isolated directly from embryos. Evans and Kaufman developed a technique for deriving cell lines through outgrowth from 129/SvE mouse blastocysts. In 1981, these experiments successfully gave rise to pluripotent embryonic stem (ES) cells that could contribute extensively to the host embryo and did not lead to tumors in adult life (Evans and Kaufman, 1981). At the same time, Gail Martin independently optimized a method to isolate and culture ES cells from mouse early blastocytes (Martin, 1981). These methods were widely adopted, and ES cells rapidly became the most popular model used in stem cell research. In subsequent years, a third type of pluripotent stem cell was obtained by outgrowth from post-implantation embryos and gonads cultured on a supporting cell layer, similar to ES cell methods. These pluripotent cells were called embryonic germ (EG) cells (Matsui et al., 1991, Resnick et al., 1992), and showed similar properties to ES cells (e.g. they could give rise to teratomas when injected into an adult host, and they could contribute to the embryo when injected into a blastocyst). ES-like cells were later derived from rhesus monkeys and marmosets, and in 1998, from human blastocysts (Thomson et al., 1998). Decades of work aimed at the identification of the transcriptional regulators that determine and maintain pluripotency in the embryo and in ES cells enabled the induction of pluripotent stem (iPS) cells from somatic cells by molecular reprogramming. iPS cells share the defining properties of ES cells, including contribution to the germline of chimeras following blastocyst injection (Takahashi and Yamanaka, 2006).

\section{Germ cell teratomas provide an opportunity to inves- tigate the intersection of pluripotency, differentiation and cancer biology}

While the short-lived popularity of EC cells as the key model of pluripotency ended with the establishment of mouse ES cell and, more recently iPS cell technologies, teratomas are of continued 
interest to both germ cell and cancer biologists because they provide a window onto the critical interface between stem cells, differentiation, and tumorigenesis. Stem cells afford enormous potential for regeneration and repair. However the risk that they will escape from growth or differentiation control (as occurs in teratomas) is a significant danger for the organism. Teratomas may hold the key to understanding how pluripotency is secured versus how unrestrained growth and/or differentiation are activated in stem cells-issues that lie at the heart of cancer, stem cell biology, and regenerative medicine, which seeks to direct the differentiation of pluripotent cells.

Although many types of stem cells are now known, germ cells are in a class of their own. They are the only known population of stem cells that retain the potential to develop into a complete organism while undergoing an elaborate differentiation process. Germ cells represent a significant regulatory challenge for the organism. They are set aside early in development and anointed as the cells that retain the blueprint for the next generation. They are responsible for carrying both the genome itself and the information about how to re-program it to the next generation. However, throughout most of an animal's lifetime, the underlying potential of germ cells is repressed, while they undergo sex-specific differentiation to form male and female gametes with highly specialized characteristics of sperm and oocytes. Despite their specialized differentiation, the underlying totipotency of germ cells is somehow preserved, and reactivated only when gametes unite to form a zygote. Testicular teratomas arise from germ cells as the result of escape from the mechanisms that repress their underlying pluripotency at a critical point during their differentiation. These tumors may result from a cell autonomous programming error in a pluripotent cell and/or an extracellular signaling interaction.

In mammals, germ cells are specified as a pluripotent cell population during early implantation stages. After specification, they migrate through the gut to the site of the developing gonads where they initiate sex-specific differentiation at E12.5 in mouse. Germ cells maintain a pluripotent state (similar to ES cells) throughout their early development, as evidenced by their ability to give rise to EG cells (Matsui et al., 1991, Resnick et al., 1992). However, once their fate is established in the testis or ovary, germ cell differentiation is unipotent, leading to sperm or oocyte development. These terminally differentiated cells do not retain pluripotent capabilities, but their fusion reinitiates a program of totipotency in the zygote. In the following section, we will review what is known about the specification of germ cells and both the establishment and repression of their underlying pluripotency.

\section{Germ cell specification and migration to the gonads}

In the mouse, germ cell precursorsare specified around E6.25 from those cells of the pluripotent epiblast proximal to the extraembryonic ectoderm (Fig. 3A). BMP signals originating in the extraembryonic ectoderm and embryonicendoderm result in the expression of Blimp1/ Prdm1 and Prdm14 in a handful of cells (Lawson etal., 1999, Ohinata et al., 2005, Yamaji et al., 2008). This process gives rise to the initial PGC population of about 40 cells near the base of the allantois by E7.5 (Ginsburg et al., 1990). BLIMP1 and PRDM14 activities lead to repression of somatic differentiation genes, expression of PGCspecific genes including a group of RNA-binding proteins, initiation of epigenetic changes, and re-expression or maintenance of core pluripotency genes (Magnusdottir et al., 2012, Ohinata et al., 2009,
Yamaji et al., 2008).

In the early embryo, the core transcription factors of pluripotency, Nanog, Sox2 and Oct4 are expressed in pluripotent cells of the inner cell mass and epiblast. These core transcription factors are necessary for the maintenance of pluripotency in the early embryo and in ES cells (Lawson et al., 1999), and ectopic Sox2 and Oct4 expression are critical to iPS cell technology (Takahashi and Yamanaka, 2006). As gastrulation begins and the germ layers are formed, these pluripotency factors are downregulated in somatic cells (Chambers et al., 2007, Yabuta et al., 2006, Yeom et al., 1996). However, Oct4 is maintained throughout germ cell specification, while Sox2 is transiently repressed then reactivated downstream of Prdm14 expression during germ cell specification (Fig. 3). It is unclear whether Nanogexpression is simply maintained or reactivated upon germ cell specification (Yabuta et al., 2006, Yamaji et al., 2008). The role of these transcription factors in PGCs is incompletely understood, but they are likely to be involved in the suppression of somatic differentiation as the germ cells undergo epigenetic reprogramming. Expression of all three genes persists until after PGCs initiate sex-specific differentiation in the gonads (Western et al., 2011, Yamaguchi et al., 2005).

After specification, PGCs use both active and passive mechanisms to travel through the developing embryo and arrive at the genital ridge between E10.5-11.5 (Molyneaux and Wylie, 2004, Saitou et al., 2012). PGCs proliferate during the early and late stages of migration surrounding a transient period of mitotic arrest in G2 at E8.5. A series of epigenetic changes to the germ cell genome begins upon specification and continues into sex-specific differentiation and after mitotic arrest in male germ cells (Fig. 3B).

Two primary forms of epigenetic reprogramming that occur in germ cells are changes in DNA methylation patterns and histone modifications (Fig. 3B). The earliest DNA demethylation begins around E8.0 when the maintenance methyltransferase, Dnmt1, and the de novo methyltransferases, Dnmt3a and Dnmt3b, are suppressed, suggesting a passive loss of methylation. During G2 mitotic arrest, demethylation continues despite the re-expression of Dnmt1, likely by an active mechanism (De Felici, 2011). Histone marks, are also modified during G2 arrest. Germ cells progressively lose H3K9me2 and increase H3K27me3, both generally repressive histone modifications that also occur in ES cells (Seki et al., 2005). Coincident with an intermediate phase when many genes have neither of these repressive marks, PGCs are transcriptionally silent due to repression of RNA polymerase II (Fig. 3B) (Seki et al., 2007).

Germ cells continue to proliferate and undergo epigenetic changes as they colonize the developing gonad. As germ cells enter the genital ridge H3K4me2, H3K4me3 and H3K9ac sharply increase (Hajkova et al., 2008, Seki et al., 2005). Further active DNA demethylation occurs at imprinted genes and at other loci associated with germ cell-specific expression at this stage (De Felici, 2011, Maatouk et al., 2006, Seki et al., 2005). While specific interdependencies of the changes that occur in germ cells are not completely understood, it is apparent that they are highly coordinated. Collectively, these changes lead to reprogrammed gametes, prepared for their differentiated fate, but retaining their underlying pluripotency.

\section{Male-specific differentiation of germ cells}

Germ cells maintain a pluripotent state (similar to ES cells) 
throughout their early development, as evidenced by their ability to form EG cells. The underlying pluripotency of germ cells during their migration and initial period of residence in the gonad (eg. prior to E12.5 in mouse) represents a risk to the animal and is under tight regulation. Once their fate is established in the testis or ovary, germ cells are reprogramed to follow a unipotent differentiation pathway, giving rise to sperm or oocytes. These differentiated gametes do not retain the ability to give rise to EG cells, but their fusion reinitiates a program of totipotency in the zygote.

Soon after colonizing the genital ridge, sex-specific differentiation of germ cells begins according to the sex of the gonad (Adams and McLaren, 2002). Here we will focus on the differentiation of male gonadal germ cells, which are incorporated into the testis cords, the nascent seminiferous tubules. Shortly thereafter, male germ cells enter mitotic arrest in G0, which persists until after birth (Western et al., 2011). The window of time in which Stevens found transplanted 129/Sv PGCs to be prone to transformation to teratoma is bracketed by PGC arrival at the gonad and their arrest in G0 of the cell cycle (Fig. 2A Table 1, Fig. 3 C,D).

Most germ cells in male gonads enter mitotic arrest between E12.5 and E14.5. At E12.5 greater than $60 \%$ of germ cells can be found in S or G2/M phases of the cell cycle. By E14.5 $80 \%$ or more of germ cells are in G1/G0 in 129T2, CD-1, and C57BL/6 mice (Western et al., 2011). Mitotic arrest in G0 likely involves regulation of the G1/S checkpoint (Fig. 3D). Proteins involved in progression of mammalian cells through the G1/S checkpoint have been investigated in male germ cells. A close look at the expression of these factors, both at the transcript and protein level, showed an initial increase in negative cell cycle regulators p27 and p15 along with a decrease in Cyclin Eexpression at E13.5. Activation of retinoblastoma protein ( $\mathrm{pRB}$ ), which also occurs at this stage, was proposed to be critical to arrest at the G1/S checkpoint (Sorrentino et al., 2007, Western et al., 2008, Western et al., 2011). However, a null mutation in pRB had a modest effect, where most germ cells still entered mitotic arrest even in the absence of pRB (Spiller et al., 2010). While many proteins involved with $\mathrm{G} 1 / \mathrm{S}$ regulation are present in germ cells at this stage, the key pathway to mitotic arrest has still not been genetically determined. It is likely that there is significant redundancy in the regulation of this critical event.

The process of reprogramming in male germ cells spans the period of mitotic arrest and likely involves genome-wide changes. Active repression of the genes associated with pluripotency is required at the stage when fetal male germ cells undergo mitotic arrest and embark on a program of differentiation as spermatogonia (Western, 2009). Failure to repress pluipotency (specifically, expression of Sox2, Nanog and Oct4), and/or failure to maintain cell cycle arrest may render germ cells susceptible to tumor formation during this critical window of development and perhaps at later stages (Cook et al., 2011, Heaney et al., 2012). However, it is not clear whether either of these events is causative. Stevens's transplantation experiments suggested that germ cells are most susceptible to teratoma transformation prior to E12.5 (Stevens, 1964). However, the earliest stage when clusters of precursor cells have been identified by elevated levels of E-cadherin and up-regulation of pluripotent markers in vivo is E15.5 (Cook et al., 2011, Heaney et al., 2012). Because likely differences in growth rates make it difficult to determine when a transformation event initiated, the period of susceptibility has not been firmly established.

At birth the mitotically quiescent germ cells, called gonocytes, are localized at the center of the seminiferous tubules. Soon after
A

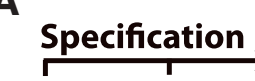

6.5

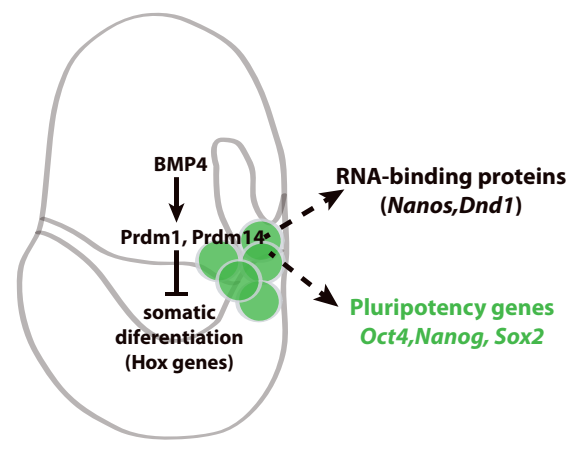

D
B
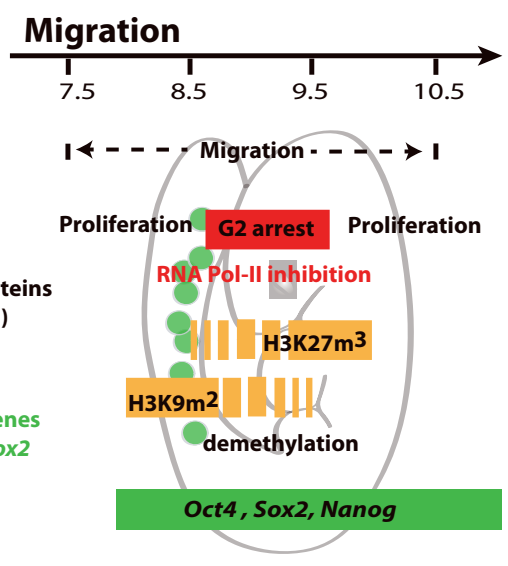

C

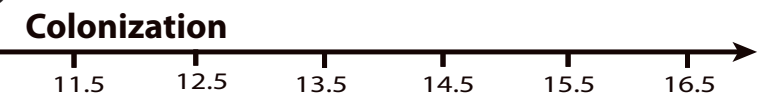

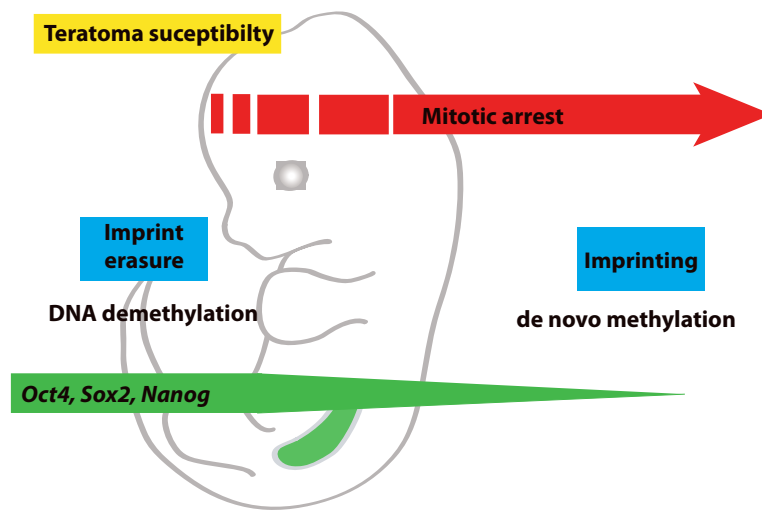

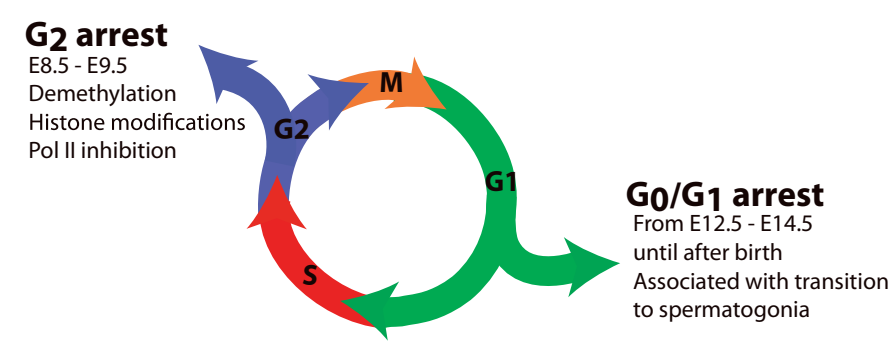

Fig. 3. Schematic representation of events during early mouse male germ cell development. Germ cells are shown as green circles in embryos from (A) E6.25; (B) E7.5 to E10.5; and (C) densely packed in a genital ridge at E11.5 to E16.5. Key processes, such as specification, gene expression, migration, cell cycle activity and epigenetic modifications are shown associated with the stage of embryo and male germ cell development. (D) Stages of the cell cycle when germ cell arrests occur. 
birth, some germ cells are lost through apoptosis, while others relocalize to the basement membrane of the seminiferous tubules, resume mitosis and differentiate into spermatogonial stem cells (SSCs), the germ line stem cells that produce sperm throughout male reproductive life (Yoshida et al., 2006) (Fig. 4). Although their differentiation trajectory is established at this stage, SSCs harbor an underlying totipotency and can still give rise to EG-like cells under appropriate explant conditions (Mochizuki and Matsui, 2010). Whether SSCs or some less differentiated progenitor is the origin of CIS leading to TGCTs in adult life is a subject of debate (Fig. 1) (Looijenga et al., 2011).

\section{Genetic influences on teratoma incidence}

The goal of much of the work on teratomas is to achieve an understanding of the molecular pathways involved in the initiation of these tumors in the hope that this will reveal something fundamental about how the pluripotent genome is regulated in germ cells, and by analogy, in other natural stem cell populations. Stevens recognized that one way of identifying the pathways involved is to investigate the factors that influence teratoma incidence (Stevens and Mackensen, 1961).

In humans, Caucasian decent and familial occurrences are both risk factors for TGCTs. While recent genome wide association studies have identified loci associated with TGCT occurrence, these loci have modest effects, suggesting that TGCT occurrence is a complex multigenic phenotype. Variants of KITLG, SPRY4, BAK1, TERT, and DMRT1 have been associated with TGCTs in genomewide association studies. Of these associations, KITLGand DMRT1 have been repeated (Kanetsky et al., 2011). Importantly, these two genes have also been shown to influence teratoma incidence in mouse models, which are discussed below.

Consistent with evidence that the incidence of human teratomas varies with ethnic background (Garner et al., 2005), experiments in mice clearly indicate that genetic background influences teratocarcinogenesis. The highest incidence of spontaneous teratomas in an inbred strain occurs in the 129/Sv testis. In addition, Stevens observed that the susceptibility to develop teratomas in the graft induction experiments was also strain dependent, with grafts from C57BL/6 mice showing no incidence of tumors (Regenass et al., 1982). Solter also classified the C57BL/6 strain as a nonpermisive strain for teratocarcinoma based on his embryo transplant experiments (Solter et al., 1979). The basis for the high susceptibility of the $129 / \mathrm{Sv}$ strain is still unclear.

Stevens showed that by crossing on mutations known to show germ cell phenotypes, he could alter the spontaneous frequency of teratomas in the 129/Sv strain. For example, as mentioned earlier, $129 / S v$ mice heterozygous at the steel locus showed an increase in tumor incidence from $1 \%$ to $10 \%$ (Stevens and Mackensen, 1961). More recently, Nadeau and colleagues derived a chromosome substitution strain, 129-Chr19 ${ }^{\mathrm{MOLF}}$, with chromosome 19 from the MOLF/ Ei strain introduced into the 129 background. This strain showed an increased tumor incidence from 5.6\% in mice from his starting 129 substrain to $23.7 \%$ and $82 \%$ in mice heterozygous or homozygous for MOLF chromosome 19, respectively (Matin et al., 1999). Strains that had only segments of MOLF chromosome 19 were generated from 129-Chr19MOLF. Analysis of teratoma incidence in these strains revealed that several regions of chromosome 19 confer teratoma susceptibility, and that interactions between these segments have both additive and epistatic relationships (Youngren et al., 2003). Heterozygous deletion of the eukaryotic initiation factor, Eif2s2, suppresses tumor incidence in the 129-Chr19 ${ }^{\mathrm{MOLF}}$ strain (Heaney et al., 2009). In a related experiment, MOLF chromosome 18 was found to be protective, decreasing the incidence of teratomas in an otherwise 129 background. Interestingly, derivation of ES cells from the blastocysts of $129-$ Chr18 ${ }^{\text {MOLF }}$ mice is significantly less efficient than derivation from 129-Chr19 MOLF mice (Anderson et al., 2009).

The transcriptional regulator, DMRT1, is another 129 specific, dose sensitive modifier of teratoma incidence. $129 \mathrm{DMRT1^{+/ } \text { and }}$ DMRT $1 \%$ mice have a $4 \%$ and $90 \%$ teratoma incidence, respectively, while homozygosity for the hypomorhic DMRT1 $1^{\text {fl }}$ allele shows an intermediate incidence of $42 \%$. DMRT1 binds the Sox2 promoter in E13.5 germ cells, and Sox2 is overexpressed in DMRT1 deficient germ cells (Krentz et al., 2009). These findings suggest that DMRT1 acts as a potent repressor of pluripotency, although it remains unclear whether misregulation of Sox2 is the primary defect. Teratomas appear to occur slightly later in fetal development in DMRT1 deficient mice, which may represent a later escape of germ cells from mitotic arrest.

Independent of the 129 strain background, homozygous disruption of Ptenin mouse germ cells leads to a $100 \%$ incidence of teratomas, while teratomas are absent in Pten heterozygotes (Kimura et al., 2003). Downregulation of Pten has been implicated in increased germ cell transformation into tumorigenic cells in culture experiments (Moe-Behrens et al., 2003). Pten, one of the most common tumor suppressor genes mutated in human cancers, codes for a lipid phosphatase that negatively regulates proliferation through dephosphorylation of phosphatidylinositol(3,4,5)-triphosphate (PIP3). EG cells can be derived from the germ cell specific Pten null mice with highly increased efficiency (Kimura et al., 2003), suggesting that releasing the brakes from the cell cycle promotes pluripotency. This is consistent with findings that ES cells transit rapidly through
Fig. 4. Schematic representation of the establishment of the spermatogonial stem cell niche and initiation of spermatogenesis. At birth (PO-P1) mitotically quiescent gonocytes are localized in the center of the seminiferous tubules. Between P2-P4, gonocytes undergo apoptosis or mi-
P0 - P1

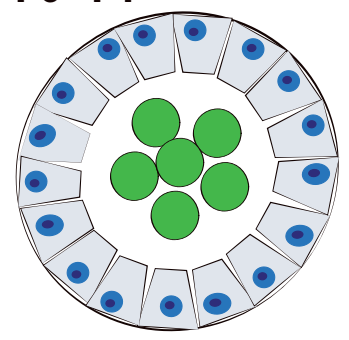

P2- P4

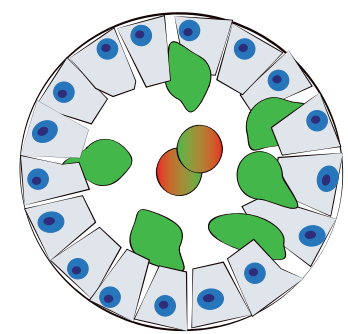

grate to the basement membrane, resume mitosis, and establish the germ line stem cell population that gives rise to spermatogenesis throughout adult life.

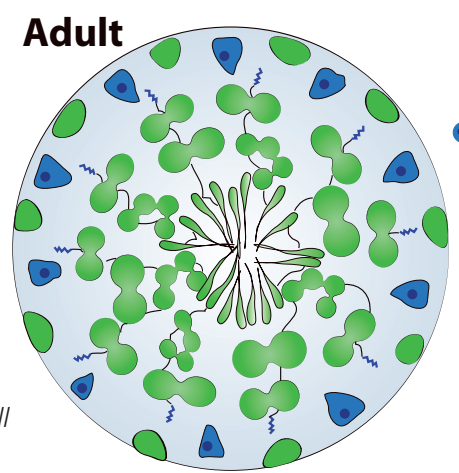

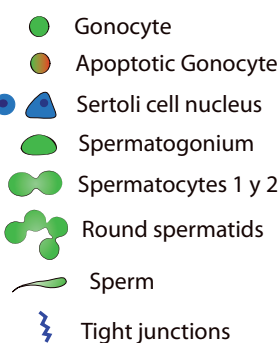

\} Tight junctions 
the cell cycle, but slow down upon differentiation (White et al., 2005). Also in accord with this idea, the maintenance of mitotic activity beyond the normal stage of mitotic arrest is associated with teratoma susceptibility in Dmrt1 ${ }^{-1}$, Pten null, and 129-Chr19MoLF mice (Heaney et al., 2012, Kimura et al., 2003, Krentz et al., 2009).

Interestingly, in Pten deleted mice, 129-Chr19 ${ }^{\mathrm{MOLF}}$ strain, and in Dnd1Ter/Ter mutants, some male germ cells express early markers of meiosis (Cook et al., 2011, Heaney et al., 2012, Kimura et al., 2003). However, no overlap has been reported between cells expressing meiotic markers and cells expressing tumor markers; thus, it is unclear whether meiosis is one of the possible differentiation pathways when mitotic arrest is blocked or delayed, or whether an initial entry into meiosis is a first step toward teratoma formation. Heterozygous deletion of Stra8, a gene associated with meiotic entry, exerted a protective effect in the context of the 129-Chr19 ${ }^{\mathrm{MOLF}}$ strain, leading to the suggestion that premature initiation of the meiotic program may promote tumorigenesis (Heaney et al., 2012).

\section{Dnd1Ter: the best-studied modifier of teratogenesis}

The sharp increase in tumor incidence in 129 mice carrying the Ter mutation suggested that Ternormally plays an important role in suppressing pluripotency, and might offer a means to identify and understand critical processes that control the balance between germ cell development and pluripotent neoplastic transformation.

The increase in the occurrence of teratomas in 129 mice caused by the Termutation was first reported in 1973 (Stevens, 1973), but the gene responsible was not identified until 2005. The Ter mutation acts as a potent modifier of the teratoma phenotype, but the background tumor incidence in 129/Sv mice, and the incomplete penetrance of the mutation indicated that Ter was neither necessary nor sufficient to cause teratomas (Matin et al., 1998). This made it difficult to use the teratoma phenotype alone to map the allele. However, the Ter mutation also caused a dramatic loss of germ cells in both sexes and in all genetic backgrounds, which allowed investigators to map the mutation to a region of chromosome 18 in 1994, and later, to a specific point mutation that introduced a premature stop codon in the dead-end homolog 1 gene (Dnd1 ${ }^{\text {Ter }}$ ) (Asada et al., 1994, Youngren et al., 2005).

Of the various factors that influence teratoma incidence, Dnd1 is the best studied from a molecular perspective. Dnd1 is the mouse ortholog of the zebrafish dead end (dnd) gene (Youngren et al., 2005). Zebrafish $d n d$ was named for its germ cell phenotype. When $d n d$ was depleted by antisense morpholinos in the early embryo, germ cells were normally specified based on early germ cell markers, but they failed to initiate migration and died by 24 hours post fertilization. Zebrafish dnd mRNA and protein localize to the germ plasm and germ granules, respectively; two related structures that are enriched for RNA binding proteins and mRNAs (Voronina et al., 2011, Weidinger et al., 2003). The major protein motif recognized in both dnd and mouse Dnd1 is a putative RNA recognition motif (RRM), suggesting that this gene plays a conserved role in germ cell post-transcriptional regulation (Weidinger et al., 2003, Youngren et al., 2005). Mouse Dnd1's RRM showed the highest similarity to mouse apobec complementation factor (ACF), a member of the RNA editing complex that converts specific cytidines to uridines in target RNAs (Mehta et al., 2000).

Throughout animal evolution, germ cell development is characterized by the presence of cytoplasmic granules containing RNAs and proteins. While these granules are referred to differently in different species, they all contain an abundance of RNA binding proteins (RBPs) (Voronina et al., 2011). Many of these RNA binding proteins themselves are highly conserved and essential for germ cell development. For example, the NANOS proteins play critical roles in germ cell specification from Drosophila to mammals. In mouse, inactivation of Nanos3 results in the disappearance of germ cells in both sexes soon after their specification, while Nanos2, which is specifically expressed in the $X Y$ gonad beginning just after germ cell colonization of the genital ridge, plays a role in suppression of meiotic genes and promotion of the male pathway. Interestingly, ectopic Nanos2 expression can rescue the Nanos3 phenotype, but Nanos3 does not rescue Nanos2, indicating incomplete overlap in their functions (Suzuki et al., 2007). NANOS2 has been shown to associate with members of the deadenylation complex and appears to negatively regulate mRNA target translation, in part by destabilization of target mRNAs (Suzuki et al., 2012).

Experimental insight into the molecular function of Dnd1 came in 2007, when it was shown in cell culture that human and mouse Dnd1 can stabilize translation of target transcripts by binding to their 3'UTRs to antagonize miRNA mediated repression of translation. Dnd1 was shown to interrupt miRNA-mRNA interactions, including the interaction between $p 27$ and miR-221, and Lats2 and miR-372. Additionally, in vivo evidence for this mechanism in zebrafish was provided for DND target transcripts nanos1 and tdrd7's interactions with miR-430 (Kedde et al., 2007).

These findings demonstrated a mechanistic role for Dnd1 and its homologs at the molecular level. The targets of DND1, Lats2 and p27, both function as cell cycle inhibitors. Mouse Dnd1 has since been shown by RNA immunoprecipitation to pull down transcripts of a group of negative regulators of the cell cycle (Cook et al., 2011). Two of these, $p 27$ and $p 21$, normally expressed during the transition to G0 in male germ cells (Western et al., 2008), were not translated in Dnd1 $1^{\text {Ter } / e r}$ mutants, and this was correlated with a failure of male germ cells to enter G0 in the mutants (Cook et al., 2011).

Questions remain about whether there are additional roles for Dnd1. ACF, the protein to which DND1 shows the greatest homology, binds with APOBEC1 to form the RNA editing complex. In the mouse there are 4 other APOBEC family members, APOBEC 1, 2, 3 and AID, and all four have deaminase activity. DND1 was shown in pull-down and colocalization experiments to interact with APOBEC3 (Bhattacharya et al., 2008). Interestingly, independent of its deaminase activity, APOBEC3 was previously shown to antagonize miRNA activity much like DND1 (Bhattacharya et al., 2008). These findings may indicate that DND1 antagonism of miRNAs requires or is regulated by other cofactors. However, DND1 could also function in RNA editing through its interaction with APOBEC3. As an RNA binding protein, DND1 may be regulating multiple mRNAs through different mechanisms at different stages of germ cell development.

The explanation for the sensitivity of the 129/Sv strain to teratoma is not clear. However, this issue has been addressed in Dnd $1^{\text {Ter/Ter }}$ mice in which teratomas arise in 129/Sv mice, but not in other strains. In most genetic backgrounds, germ cells are almost completely lost in Dnd1 ${ }^{\text {TerTer }}$ mice consistent with the early defect in germ cell specification (Noguchi et al., 1996). This led to the idea that more efficient cell death pathways might protect certain strains by eliminating errant germ cells prior to tumor initiation. To explore the question of whether germ cell loss was a protective factor in non-129/Sv strains, a mutation in the pro-apoptotic gene Bax was 
introduced into mice of several genetic backgrounds carrying the Dnd1 $1^{\text {Ter }}$ mutation. Elimination $\left(\mathrm{Bax}^{\wedge}\right)$ or reduction $\left(\mathrm{Bax}^{+-}\right)$of $\mathrm{Bax}$ function in mice partially rescued the germ cell loss phenotype in all strains. As predicted, a high incidence of teratomas was detected in double mutant Dnd1 $1^{\text {TerTer }}$, Bax ${ }^{/-}$as well as in Dnd1 $1^{\text {TerTer }}$, Bax ${ }^{/ /}$mice on mixed genetic backgrounds, where teratomas were not seen in the absence of the Bax mutation. However, on a pure C57BL/6 background where $\sim 50 \%$ of germ cells were rescued, no teratomas were seen, even in double mutants (Cook et al., 2009).

In a gene expression comparison in E14.5 XY germ cells, cell cycle regulators, cell death pathways, and tumor suppressors were found to be among the genes enriched in C57BL/6 compared to 129/Sv (Cook et al., 2011). These findings suggest that an elevation in the factors that promote cell cycle arrest or apoptotic pathways prior to the mitotic arrest stage of germ cell development may be sufficient to prevent teratoma formation, even in the presence of a homozygous mutation in Dnd1. A better understanding of the genetic basis for 129/Sv tumor susceptibility versus C57BL/6 tumor resistance could lead to the identification of additional genetic factors/modifiers that allow germ cells to escape from the regulators that control their underlying pluripotency.

\section{Environmental influences on left-right asymmetry in teratoma incidence}

Importantly, it is still unknown what role somatic cells and/or whole animal physiology plays in the sensitivity of the 129/Sv strain to teratoma development. Although expression of $D n d 1$ is limited to germ cells (Cook et al., 2009), decisions about cell death versus cell cycle progression are strongly influenced by the signaling environment in the testis and perhaps in the whole animal. Left-right asymmetry in tumor incidence is an in vivo example of how subtle micro-environmental differences may affect tumor incidence.

Stevens reported that $75 \%$ of teratomas were found in the left testis, suggesting a heritable genetic or physiological difference that affects the left gonad. An interesting possibility to explain the bias in teratoma development is the genetic control of laterality. Asymmetric left/right gene expression begins at gastrulation when several regulatory genes are expressed in the left lateral plate mesoderm (Lee and Anderson, 2008). The molecular networks that regulate left-right asymmetry are different in different species; however, some mechanisms seem to be highly conserved (Levin, 2005). The earliest gene expressed asymmetrically in the lateral plate mesoderm is Nodal, which belongs to the TGF- $\beta$ superfamily (Lee and Anderson, 2008, Levin, 2005). Nodal and its receptor Cripto are expressed transiently in male germ cells between E12.5-E13.5, and compromised expression leads to premature differentiation of germ cells (Spiller et al., 2012). Nodal promotes plasticity of both embryonic and tumor stem cells and re-expression of Nodal in tumorigenic cells (Postovit et al., 2007) and in testicular tumors (Spiller et al., 2012) has been associated with a poor prognosis. Although there is currently no evidence that Nodal is expressed asymmetrically in the developing gonad, these studies suggest a possible link between the molecular control of left-right asymmetry and teratoma bias to the left side.

Stevens proposed that the lateral asymmetry could be related to vascular differences between the left and right testis (Stevens and Little, 1954). To test this idea, Stevens crossed the situs inversus viscerum gene onto the $129 / \mathrm{Sv}$ strain and found that the sidedness of the teratoma incidence reversed to the right testis. Based on this work, Stevens proposed that vasculature influences teratocarcinogenesis (Stevens, 1982). It is accepted that the microenvironment plays a role in establishing the niche for stem cells. For example, nutrient availability influences germ line stem cell fate in Drosophila (Hsu et al., 2008). In addition, low oxygen tension environment (hypoxia) maintains the undifferentiated states of embryonic, hematopoietic, mesenchymal, and neural stem cells, and can also influence proliferation, cell-fate commitment, and cancer (Mohyeldin et al., 2010). It is possible that left-right variations in testis vascularization could cause differential delivery of nutrients or a hypoxic environment during early germ cell development that result in asymmetric tumor incidence in the 129/Sv Dnd1 ${ }^{\text {Ter }}$ mice. The study of left-right asymmetry in tumor development could lead to important discoveries of additional environmental or physiological mechanisms that are involved in susceptibility of stem cells to tumorigenesis.

\section{Conclusions}

Teratomas, the most common form of TGCT affecting young men and boys, were among the earliest documented tumors. The capacity to produce all three germ layers places testicular teratomas at the crux of stem cell and cancer biology, and the study of these unusual tumors may hold clues about how natural populations of stem cells are regulated and how their differentiation is controlled. 129 mice have historically been and continue to be the most researched animal model of germ line teratomas. Early research with these teratomas paved the way for the development of ES cell technology. A variety of modifiers of teratoma incidence have been identified, the most widely studied, and one of the most potent of which is a mutation in the Dnd1 gene. This RNA binding protein post-transcriptionally regulates multiple target RNAs by antagonizing miRNA mediated repression and possibly through RNA editing or other mechanisms. Perhaps the most critical question is how misregulation of DND1 targets leads specifically to teratoma development rather than to more uniform neoplasms resulting from unbridled proliferation. Although other forms of TGCTs arise at later stages, presumably also resulting from misregulation of the cell cycle, development of teratomas seems to be limited to stages of male germ cell development surrounding the initiation of mitotic arrest in fetal life. This implies that totipotent pathways of embryonic differentiation are still available to male germ cells prior to the reprogramming events that occur during mitotic arrest. Exactly what those reprogramming events entail, and how they are mechanistically achieved, may reveal the links between regulation of the cell cycle, differentiation and neoplastic transformation.

\section{Acknowledgements}

We thank Danielle Maatouk for her help editing this manuscript. We thank Lindsey Mork for the design of images depicting early embryonic stages that we have modified for our figures. We are also very appreciative of our funding from the Lalor Foundation and Comisión Nacional de Investigación Científica y Tecnológica (CONICYT), Chile to XBM, as well as from NIGMS to $B C$ for the laboratory's work on testicular teratomas.

\section{References}

ADAMS, I.R. and MCLAREN, A. (2002). Sexually dimorphic development of mouse primordial germ cells: switching from oogenesis to spermatogenesis. Develop- 
ment 129: 1155-1164

ANDERSON, P.D., NELSON, V.R., TESAR, P.J. and NADEAU, J.H. (2009). Genetic factors on mouse chromosome 18 affecting susceptibility to testicular germ cell tumors and permissiveness to embryonic stem cell derivation. Cancer Res 69: 9112-9117.

ASADA, Y., VARNUM, D.S., FRANKEL, W.N. and NADEAU, J.H. (1994). A mutation in the Ter gene causing increased susceptibility to testicular teratomas maps to mouse chromosome 18. Nat Genet 6: 363-368.

BHATTACHARYA, C., AGGARWAL, S., KUMAR, M., ALI, A. and MATIN, A. (2008). Mouse Apolipoprotein B Editing Complex 3 (APOBEC3) Is Expressed in Germ Cells and Interacts with Dead-End (DND1). PLoS One 3: e2315.

BRINSTER, R.L. (1974). The effect of cells transferred into the mouse blastocyst on subsequent development. J. Exp. Med. 140: 1049-1056.

CHAMBERS, I., SILVA, J., COLBY, D., NICHOLS, J., NIJMEIJER, B., ROBERTSON, M., VRANA, J., JONES, K., GROTEWOLD, L. and SMITH, A. (2007). Nanog safeguards pluripotency and mediates germline development. Nature 450: 1230-1234.

COOK, M.S., COVENEY, D., BATCHVAROV, I., NADEAU, J.H. and CAPEL, B. (2009). BAX-mediated cell death affects early germ cell loss and incidence of testicular teratomas in Dnd1(Ter/Ter) mice. Dev Biol 328: 377-383.

COOK, M.S., MUNGER, S.C., NADEAU, J.H. and CAPEL, B. (2011). Regulation of male germ cell cycle arrest and differentiation by DND1 is modulated by genetic background. Development 138: 23-32.

DAMJANOV, I., SOLTER, D., BELICZA, M. and ŠKREB, N. (1971). Teratomas Obtained Through Extrauterine Growth of Seven-Day Mouse Embryos. J Natl Cancer Inst 46: 471-480.

DE FELICI, M. (2011). Nuclear reprogramming in mouse primordial germ cells: epigenetic contribution. Stem Cells Int 2011: 425863.

DIXON, F.J. and MOORE, R.A. (1953). Testicular tumors. A clinicopathological study. Cancer 6: 427-454.

EGEVAD, L., HeANUE, M., BERNEY, D., Fleming, K. and FERLAY, J. (2007). Histological groups. In Cancer Incidence in Five Continents Vol. IX, vol. IX (ed. CURADO, M. P.EDWARDS, B.SHIN, H. R. S., H.FERLAY, J.M., H. and P., B.). Lyon, France: International Agency for Research on Cancer.

EVANS, M.J. and KAUFMAN, M.H. (1981). Establishment in culture of pluripotential cells from mouse embryos. Nature 292: 154-156.

FALIN, L.I. (1940). Experimental Teratoma Testis in the Fowl. Am. J. Cancer38: 199-211.

GARNER, M.J., TURNER, M.C., GHADIRIAN, P. and KREWSKI, D. (2005). Epidemiology of testicular cancer: an overview. Int J Cancer 116: 331-339.

GINSBURG, M., SNOW, M.H. and MCLAREN, A. (1990). Primordial germ cells in the mouse embryo during gastrulation. Development 110: 521-528.

HAJKOVA, P., ANCELIN, K., WALDMANN, T., LACOSTE, N., LANGE, U.C., CESARI, F., LEE, C., ALMOUZNI, G., SCHNEIDER, R. and SURANI, M.A. (2008). Chromatin dynamics during epigenetic reprogramming in the mouse germ line. Nature 452: 877-881.

HEANEY, J.D., ANDERSON, E.L., MICHELSON, M.V., ZECHEL, J.L., CONRAD, P.A., PAGE, D.C. and NADEAU, J.H. (2012). Germ cell pluripotency, premature differentiation and susceptibility to testicular teratomas in mice. Development 139: 1577-1586.

HEANEY, J.D., MICHELSON, M.V., YOUNGREN, K.K., LAM, M.-Y.J. and NADEAU, J.H. (2009). Deletion of elF2beta suppresses testicular cancer incidence and causes recessive lethality in agouti-yellow mice. Hum Mol Genet 18: 1395-1404.

HOLDEN, S., BERNARD, O., ARTZT, K., WHITMORE, W.F. and BENNETT, D. (1977). Human and mouse embryonal carcinoma cells in culture share an embryonic antigen (F9). Nature 270: 518-520.

HSU, H.-J., LAFEVER, L. and DRUMMOND-BARBOSA, D. (2008). Diet controls normal and tumorous germline stem cells via insulin-dependent and -independent mechanisms in Drosophila. Dev Biol 313: 700-712.

KANETSKY, P.A., MITRA, N., VARDHANABHUTI, S., VAUGHN, D.J., LI, M., CIOSEK, S.L., LETRERO, R., D'ANDREA, K., VADDI, M., DOODY, D.R. et al., (2011). A second independent locus within DMRT1 is associated with testicular germ cell tumor susceptibility. Hum Mol Genet 20: 3109-3117.

KEDDE, M., STRASSER, M.J., BOLDAJIPOUR, B., OUDE VRIELINK, J.A., SLANCHEV, K., LE SAGE, C., NAGEL, R., VOORHOEVE, P.M., VAN DUIJSE, J., OROM, U.A. et al., (2007). RNA-binding protein Dnd1 inhibits microRNA access to target mRNA. Cell 131: 1273-1276.
KIMURA, T., SUZUKI, A., FUJITA, Y., YOMOGIDA, K., LOMELI, H., ASADA, N., IKEUCHI, M., NAGY, A., MAK, T.W. and NAKANO, T. (2003). Conditional loss of PTEN leads to testicular teratoma and enhances embryonic germ cell production. Development 130: 1691-1700.

KLEINSMITH, L.J. and PIERCE, G.B., JR. (1964). Multipotentiality of Single Embryonal Carcinoma Cells. Cancer Res 24: 1544-1551.

KRENTZ, A.D., MURPHY, M.W., KIM, S., COOK, M.S., CAPEL, B., ZHU, R., MATIN, A., SARVER, A.L., PARKER, K.L., GRISWOLD, M.D. etal., (2009). The DM domain protein DMRT1 is a dose-sensitive regulator of fetal germ cell proliferation and pluripotency. Proc Natl Acad Sci USA 106: 22323-22328.

LAWSON, K.A., DUNN, N.R., ROELEN, B.A.J., ZEINSTRA, L.M., DAVIS, A.M., WRIGHT, C.V.E., KORVING, J. and HOGAN, B.L.M. (1999). Bmp4 is required for the generation of primordial germ cells in the mouse embryo. Genes Dev 13: 424-436.

LEE, J.D. and ANDERSON, K.V. (2008). Morphogenesis of the node and notochord: the cellular basis for the establishment and maintenance of left-right asymmetry in the mouse. Dev Dyn 237: 3464-3476.

LEVIN, M. (2005). Left-right asymmetry in embryonic development: a comprehensive review. Mech Dev 122: 3-25.

LOOIJENGA, L.H.J., GILLIS, A.J.M., STOOP, H., BIERMANN, K. and OOSTERHUIS, J.W. (2011). Dissecting the molecular pathways of (testicular) germ cell tumour pathogenesis; from initiation to treatment-resistance. Int J Androl 34: e234-e251.

MAATOUK, D.M., KELLAM, L.D., MANN, M.R.W., LEI, H., LI, E., BARTOLOMEI, M.S. and RESNICK, J.L. (2006). DNA methylation is a primary mechanism for silencing postmigratory primordial germ cell genes in both germ cell and somatic cell lineages. Development 133: 3411-3418.

MAGNUSDOTTIR, E., GILLICH, A., GRABOLE, N. and SURANI, M.A. (2012). Combinatorial control of cell fate and reprogramming in the mammalian germline. Curr Opin Genet Dev. 22: 466-474.

MARTIN, G.R. (1981). Isolation of a Pluripotent Cell Line from Early Mouse Embryos Cultured in Medium Conditioned by Teratocarcinoma Stem Cells. Proc Natl Acad Sci USA 78: 7634-7638.

MATIN, A., COLLIN, G.B., ASADA, Y., VARNUM, D. and NADEAU, J.H. (1999). Susceptibility to testicular germ-cell tumours in a 129.MOLF-Chr 19 chromosome substitution strain. Nat Genet 23: 237-240.

MATIN, A., COLLIN, G.B., VARNUM, D.S. and NADEAU, J.H. (1998). Testicular teratocarcinogenesis in mice - a review. APMIS 106: 174-182.

MATSUI, Y., TOKSOZ, D., NISHIKAWA, S., WILLIAMS, D., ZSEBO, K. and HOGAN, B.L. (1991). Effect of Steel factor and leukaemia inhibitory factor on murine primordial germ cells in culture. Nature 353: 750-752.

MEHTA, A., KINTER, M.T., SHERMAN, N.E. and DRISCOLL, D.M. (2000). Molecular cloning of apobec-1 complementation factor, a novel RNA-binding protein involved in the editing of apolipoprotein B mRNA. Molec. Cell Biol. 20: 1846-1854.

MELICOW, M.M. (1955). Classification of tumors of testis: a clinical and pathological study based on 105 primary and 13 secondary cases in adults, and 3 primary and 4 secondary cases in children. $J$ Urol 73: 547-574.

MINTZ, B. and FLEISCHMAN, R.A. (1981). Teratocarcinomas and Other Neoplasms as Developmental Defects in Gene Expression. In Advances in Cancer Research, vol. Volume 34 (ed. GEORGE, K. and SIDNEY, W.). Academic Press, pp.211-278.

MINTZ, B. and ILLMENSEE, K. (1975). Normal Genetically Mosaic Mice Produced from Malignant Teratocarcinoma Cells. Proc Natl Acad Sci USA 72: 3585-3589.

MOCHIZUKI, K. and MATSUI, Y. (2010). Epigenetic profiles in primordial germ cells: global modulation and fine tuning of the epigenome for acquisition of totipotency. Dev Growth Differ 52: 517-525.

MOE-BEHRENS, G.H.G., KLINGER, F.G., ESKILD, W., GROTMOL, T., HAUGEN, T.B. and DE FELICI, M. (2003). Akt/PTEN Signaling Mediates Estrogen-Dependent Proliferation of Primordial Germ Cells in Vitro. Molec. Endocrinol. 17: 2630-2638.

MOHYELDIN, A., GARZON-MUVDI, T. and QUINONES-HINOJOSA, A. (2010). Oxygen in stem cell biology: a critical component of the stem cell niche. Cell Stem Cell 7: 150-161.

MOLYNEAUX, K. and WYLIE, C. (2004). Primordial germ cell migration. Int J Dev Biol 48: 537-543.

NCI. (2012). Nationall Cancer Institute, (ed. http://www.cancer.gov).

NOGUCHI, M., WATANABE, C., KOBAYASHI, T., KUWASHIMA, M., SAKURAI, T., $\mathrm{KATOH}, \mathrm{H}$. and MORIWAKI, K. (1996). The ter mutation responsible for germ cell 
deficiency but not testicular nor ovarian teratocarcinogenesis in ter / ter congenic mice. Dev Growth Differ 38: 59-69.

OHINATA, Y., OHTA, H., SHIGETA, M., YAMANAKA, K., WAKAYAMA, T. and SAITOU, M. (2009). A Signaling Principle for the Specification of the Germ Cell Lineage in Mice. Cell 137: 571-584.

OHINATA, Y., PAYER, B., O'CARROLL, D., ANCELIN, K., ONO, Y., SANO, M., BARTON, S.C., OBUKHANYCH, T., NUSSENZWEIG, M., TARAKHOVSKY, A. et al., (2005). Blimp1 is a critical determinant of the germ cell lineage in mice. Nature 436: 207-213.

PANTOJA, E. and RODRIGUEZ-LBAÑEZ, I. (1976). Sacrococcygeal dermoids and teratomas: Historical review. Am. J. Surgery 132: 377-383.

PAPAIOANNOU, V.E., MCBURNEY, M.W., GARDNER, R.L. and EVANS, M.J. (1975). Fate of teratocarcinoma cells injected into early mouse embryos. Nature258:70-73.

POSTOVIT, L.M., COSTA, F.F., BISCHOF, J.M., SEFTOR, E.A., WEN, B., SEFTOR, R.E., FEINBERG, A.P., SOARES, M.B. and HENDRIX, M.J. (2007). The commonality of plasticity underlying multipotent tumor cells and embryonic stem cells. J Cell Biochem 101: 908-917.

REGENASS, U., FRIEDRICH, T.D. and STEVENS, L.C. (1982). Experimental induction of testicular teratomas in dissociated-reaggregated chimaeric gonads. J. Embryol. Exp. Morphol. 72: 153-167.

RESNICK, J.L., BIXLER, L.S., CHENG, L. and DONOVAN, P.J. (1992). Long-term proliferation of mouse primordial germ cells in culture. Nature 359: 550-551.

RICHARDSON, L.C., WINGO, P.A., ZACK, M.M., ZAHRAN, H.S. and KING, J.B. (2008). Health-related quality of life in cancer survivors between ages 20 and 64 years: population-based estimates from the Behavioral Risk Factor Surveillance System. Cancer 112: 1380-1389.

SAITOU, M., KAGIWADA, S. and KURIMOTO, K. (2012). Epigenetic reprogramming in mouse pre-implantation development and primordial germ cells. Development 139: 15-31.

SEKI, Y., HAYASHI, K., ITOH, K., MIZUGAKI, M., SAITOU, M. and MATSUI, Y. (2005). Extensive and orderly reprogramming of genome-wide chromatin modifications associated with specification and early development of germ cells in mice. Dev Biol 278: 440-458.

SEKI, Y., YAMAJI, M., YABUTA, Y., SANO, M., SHIGETA, M., MATSUI, Y., SAGA, Y., TACHIBANA, M., SHINKAI, Y. and SAITOU, M. (2007). Cellular dynamics associated with the genome-wide epigenetic reprogramming in migrating primordial germ cells in mice. Development 134: 2627-2638.

SOLTER, D. (2006). Timeline - From teratocarcinomas to embryonic stem cells and beyond: a history of embryonic stem cell research. Nature Rev. Genet. 7:319-327.

SOLTER, D., DOMINIS, M. and DAMJANOV, I. (1979). Embryo-derived teratocarcinoma: I. The role of strain and gender in the control of teratocarcinogenesis. Int. J. Cancer 24: 770-772.

SOLTER, D., DOMINIS, M. and DAMJANOV, I. (1980). Embryo-derived teratocarcinoma II. Teratocarcinogenesis depends on the type of embryonic graft. Int. J. Cancer 25: 341-343.

SORRENTINO, E., NAZZICONE, V., FARINI, D., CAMPAGNOLO, L. and DE FELICI, M. (2007). Comparative transcript profiles of cell cycle-related genes in mouse primordial germ cells, embryonic stem cells and embryonic germ cells. Gene Expression Patterns 7: 714-721.

SPILLER, C.M., FENG, C.-W., JACKSON, A., GILLIS, A.J.M., ROLLAND, A.D., LOOIJENGA, L.H.J., KOOPMAN, P. and BOWLES, J. (2012). Endogenous Nodal signaling regulates germ cell potency during mammalian testis development. Development.

SPILLER, C.M., WILHELM, D. and KOOPMAN, P. (2010). Retinoblastoma 1 Protein Modulates XY Germ Cell Entry into G1/G0 Arrest During Fetal Development in Mice. Biol Reprod 82: 433-443.

STEVENS, L.C. (1959). Embryology of Testicular Teratomas in Strain 129 Mice. J Natl Cancer Inst 23: 1249-1261, NP1, 1262-1295.

STEVENS, L.C. (1964). Experimental Production of Testicular Teratomas in Mice. Proc Natl Acad Sci USA 52: 654-561.

STEVENS, L.C. (1967). Origin of testicular teratomas from primordial germ cells in mice. J Natl Cancer Inst 38: 549-552.

STEVENS, L.C. (1973). Anew inbred subline of mice (129-terSv) with a high incidence of spontaneous congenital testicular teratomas. J Natl Cancer Inst 50: 235-242.

STEVENS, L.C. (1982). Genetic influences on teratocarcinogenesis in mice. In Genetic approaches to developmental neurobiology, vol. 1 (ed. TSUKADA, Y.) University of Tokio Tokyo, pp.87-94.

STEVENS, L.C. and LITTLE, C.C. (1954). Spontaneous Testicular Teratomas in an Inbred Strain of Mice. Proc Natl Acad Sci USA 40: 1080-107.

STEVENS, L.C. and MACKENSEN, J.A. (1961). Genetic and Environmental Influences on Teratocarcinogenesis in Mice. J Natl Cancer Inst 27: 443-453.

SUZUKI, A., SABA, R., MIYOSHI, K., MORITA, Y. and SAGA, Y. (2012). Interaction between NANOS2 and the CCR4-NOT Deadenylation Complex Is Essential for Male Germ Cell Development in Mouse. PLoS One 7: e33558.

SUZUKI, A., TSUDA, M. and SAGA, Y. (2007). Functional redundancy among Nanos proteins and a distinct role of Nanos2 during male germ cell development. Development 134: 77-83.

TAKAHASHI, K. and YAMANAKA, S. (2006). Induction of Pluripotent Stem Cells from Mouse Embryonic and Adult Fibroblast Cultures by Defined Factors. Cell 126: 663-676.

TCS. (2012). Testicular Cancer Society, (http://www.testicularcancersociety.org/ understanding_testicular_cancer.html).

THOMSON, J.A., ITSKOVITZ-ELDOR, J., SHAPIRO, S.S., WAKNITZ, M.A., SWIERGIEL, J.J., MARSHALL, V.S. and JONES, J.M. (1998). Embryonic Stem Cell Lines Derived from Human Blastocysts. Science 282: 1145-1147.

VORONINA, E., SEYDOUX, G., SASSONE-CORSI, P. and NAGAMORI, I. (2011). RNA Granules in Germ Cells. CSH Pers. Biol. 3.

WEIDINGER, G., STEBLER, J., SLANCHEV, K., DUMSTREI, K., WISE, C., LOVELLBADGE, R., THISSE, C., THISSE, B. and RAZ, E. (2003). dead end, a Novel Vertebrate Germ Plasm Component, Is Required for Zebrafish Primordial Germ Cell Migration and Survival. Curr. Biol. 13: 1429-1434.

WESTERN, P. (2009). Foetal germ cells: striking the balance between pluripotency and differentiation. Int J Dev Biol 53: 393-409.

WESTERN, P.S., MILES, D.C., VAN DEN BERGEN, J.A., BURTON, M. and SINCLAIR, A.H. (2008). Dynamic regulation of mitotic arrest in fetal male germ cells. Stem Cells 26: 339-347.

WESTERN, P.S., RALLI, R.A., WAKELING, S.I., LO, C., VAN DEN BERGEN, J.A., MILES, D.C. and SINCLAIR, A.H. (2011). Mitotic arrest in teratoma susceptible fetal male germ cells. PLoS One 6: e20736.

WHITE, J., STEAD, E., FAAST, R., CONN, S., CARTWRIGHT, P. and DALTON, S. (2005). Developmental Activation of the Rb-E2F Pathway and Establishment of Cell Cycle-regulated Cyclin-dependent Kinase Activity during Embryonic Stem Cell Differentiation. Molec. Biol. Cell 16: 2018-2027.

YABUTA, Y., KURIMOTO, K., OHINATA, Y., SEKI, Y. and SAITOU, M. (2006). Gene Expression Dynamics During Germline Specification in Mice Identified by Quantitative Single-Cell Gene Expression Profiling. Biol Reprod 75: 705-716.

YAMAGUCHI, S., KIMURA, H., TADA, M., NAKATSUJI, N. and TADA, T. (2005) Nanog expression in mouse germ cell development. Gene Exp. Patt. 5: 639-646.

YAMAJI, M., SEKI, Y., KURIMOTO, K., YABUTA, Y., YUASA, M., SHIGETA, M., YAMANAKA, K., OHINATA, Y. and SAITOU, M. (2008). Critical function of Prdm14 for the establishment of the germ cell lineage in mice. Nat Genet 40: 1016-1022.

YEOM, Y.I., FUHRMANN, G., OVITT, C.E., BREHM, A., OHBO, K., GROSS, M., HUBNER, K. and SCHOLER, H.R. (1996). Germline regulatory element of Oct-4 specific for the totipotent cycle of embryonal cells. Development 122: 881-894.

YOSHIDA, S., SUKENO, M., NAKAGAWA, T., OHBO, K., NAGAMATSU, G., SUDA, T. and NABESHIMA, Y. (2006). The first round of mouse spermatogenesis is a distinctive program that lacks the self-renewing spermatogonia stage. Development 133: 1495-1505

YOUNGREN, K.K., COVENEY, D., PENG, X., BHATTACHARYA, C., SCHMIDT, L.S., NICKERSON, M.L., LAMB, B.T., DENG, J.M., BEHRINGER, R.R., CAPEL, B. et al., (2005). The Ter mutation in the dead end gene causes germ cell loss and testicular germ cell tumours. Nature 435: 360-364.

YOUNGREN, K.K., NADEAU, J.H. and MATIN, A. (2003). Testicular cancer susceptibility in the 129.MOLF-Chr19 mouse strain: additive effects, gene interactions and epigenetic modifications. Hum Mol Genet 12: 389-398. 


\section{Further Related Reading, published previously in the Int. J. Dev. Biol.}

The internal structure of embryonic gonads and testis development in Drosophila melanogaster requires scrib, Igl and dlg activity in the soma

Fani Papagiannouli

Int. J. Dev. Biol. (2013) 57: 25 - 34

The migration and loss of human primordial germ stem cells from the hind gut epithelium towards the gonadal ridge Linn Salto Mamsen, Christian Beltoft Brøchner, Anne Grete Byskov and Kjeld Møllgard

Int. J. Dev. Biol. (2012) 56: 771 - 778

Germline stem cells and sex determination in Hydra

Chiemi Nishimiya-Fujisawa and Satoru Kobayashi

Int. J. Dev. Biol. (2012) 56: 499 - 508

Impaired meiotic competence in putative primordial germ cells produced from mouse embryonic stem cells

Marianna Tedesco, Donatella Farini and Massimo De Felici

Int. J. Dev. Biol. 55: 215 - 222 (2011)

Analysis of SOX2 expression in developing human testis and germ cell neoplasia Si B. Sonne, Rebecca M. Perrett, John E. Nielsen, Melissa A. Baxter, David M. Kristensen, Henrik Leffers, Neil A. Hanley and Ewa Rajpert-De-Meyts Int. J. Dev. Biol. (2010) 54: 755 - 760

The germ cell-the mother of all stem cells P J Donovan

Int. J. Dev. Biol. (1998) 42: 1043 - 1050

5 yr ISI Impact Factor $(2011)=2.959$
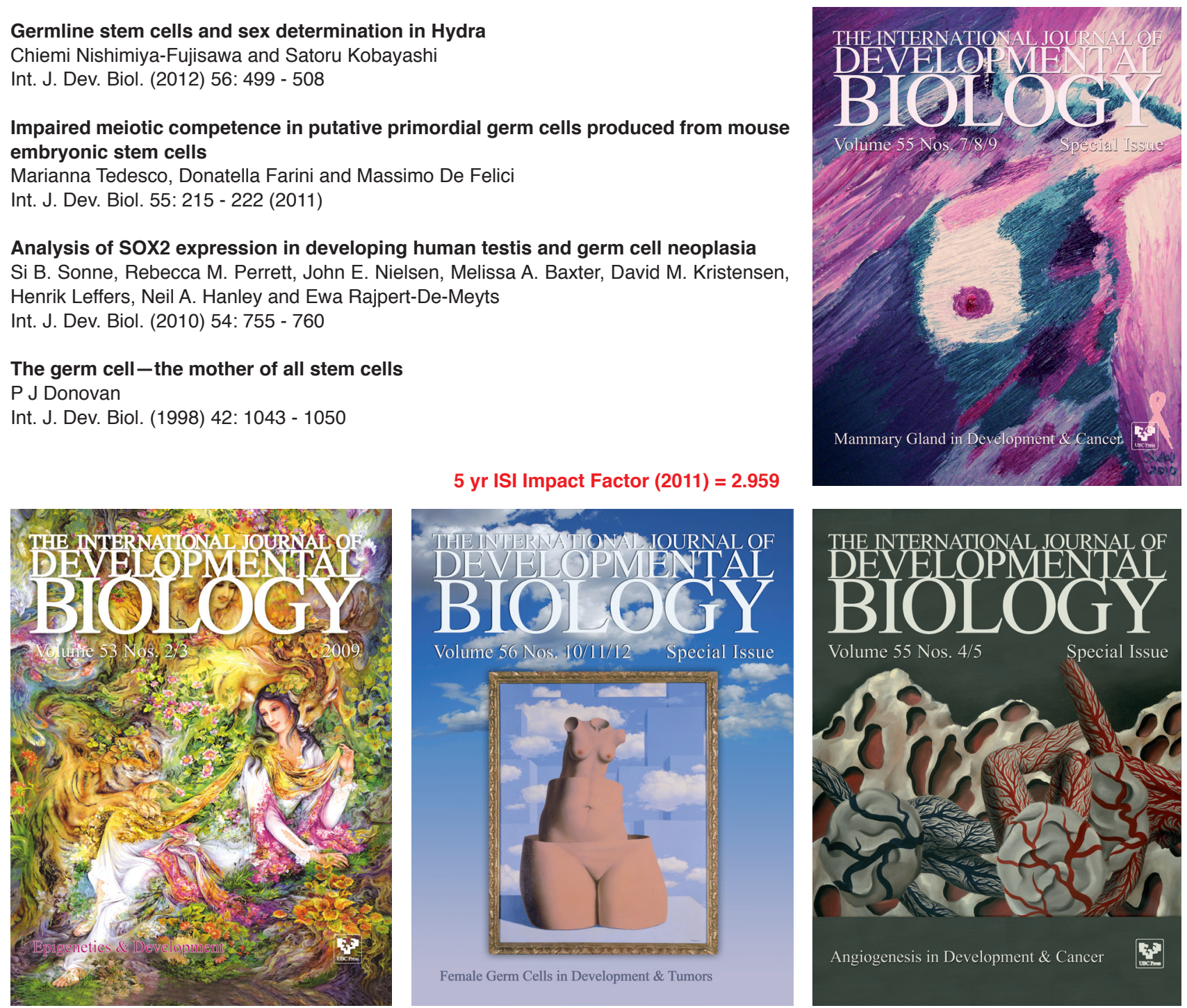